\title{
SOL-GEL SYNTHESIS OF NANOSIZED LANTHANIDE-DOPED MIXED-METAL GARNETS
}

\author{
S. Šakirzanovas and A. Kareiva \\ Faculty of Chemistry, Vilnius University, Naugarduko 24, LT-03225 Vilnius, Lithuania \\ E-mail: aivaras.kareiva@chf.vu.lt
}

Received 14 December 2006

\begin{abstract}
Lanthanide-doped mixed-metal garnets $\mathrm{RE}: \mathrm{Y}_{3} \mathrm{Sc}_{2} \mathrm{AlGa}_{2} \mathrm{O}_{12}(\mathrm{RE}=\mathrm{Nd}, \mathrm{Ho}, \mathrm{Er}, \mathrm{Tb}, \mathrm{Dy}, \mathrm{Yb})$ have been synthesized using an aqueus sol-gel synthesis route. Results obtained by different characterization techniques (FTIR, XRD, ICP, SEM, TEM) revealed no influence of a doping element on the morphology and phase purity of the synthesized samples. However, electron diffraction images showed streakings which indicated that different point or planar defects occured in the structure of synthesized garnets.
\end{abstract}

Keywords: sol-gel, mixed-metal garnet, rare-earth metals

PACS: 42.70.-a, 61.46.-w, 68.37.Hk, 68.37.Lp

\section{Introduction}

The specific properties of metal oxide ceramics are highly sensitive to the host material, dopant composition and concentration, host stoichiometry, and processing conditions [1-3]. Thus, the physical properties of garnets are usually controlled by varying their composition with the aim of preparing isomorphous solid solutions by choosing appropriate conditions of synthesis [4]. In the context of doped materials, incorporation of homogeneously distributed nanosized secondary phases into a host matrix can be realized by the molecular level fabrication of new materials. Subsequent treatment of the materials in such a way leads to the formation of specific point defects and crystalline ordering or, in other words, this ensures a particular distribution of ions and defects over crystallographically nonequivalent positions in the garnet structure [5].

In order to combine the favourable properties of glasses (i.e., broad emission bandwidth) and crystals (i.e., good thermo-mechanical properties), the rare-earth (RE) doped disordered ceramic materials $\mathrm{RE}: \mathrm{Y}_{3} \mathrm{Sc}_{2} \mathrm{AlGa}_{2} \mathrm{O}_{12}$ (YSAGG) were synthesized using an aqueous sol-gel method. These materials are solid solutions of $\mathrm{Y}_{3} \mathrm{Al}_{5} \mathrm{O}_{12}$ (YAG), $\mathrm{Y}_{3} \mathrm{Sc}_{2} \mathrm{Al}_{3} \mathrm{O}_{12}$ (YSAG), and $\mathrm{Y}_{3} \mathrm{Ga}_{5} \mathrm{O}_{12}$ (YGG). The ceramic materials have the advantage in comparison to a single crystal: a flexible fabrication route and homogenous incor- poration of trivalent rare-earth doping ion into a host matrix [6].

There are several reasons for examining the properties of RE: $\mathrm{Y}_{3} \mathrm{Sc}_{2} \mathrm{AlGa}_{2} \mathrm{O}_{12}$ in greater detail. The distribution coefficient for RE in YSAGG is much higher than in YAG, making it possible to increase the RE concentration in YSAGG more than in YAG. Replacement of $\mathrm{Al}^{3+}$ ions with larger $\mathrm{Sc}^{3+}$ ions increases the distance between dodecahedral lattice sites (substitution sites for RE ions in the garnet structure). Any increase in separation between neighbouring RE ions tends to reduce the relatively strong ion-ion interaction in a host matrix, which reduces the concentration quenching of RE fluorescence [7]. For example, the spectroscopic properties of $\mathrm{Nd}: \mathrm{Y}_{3} \mathrm{Sc}_{x} \mathrm{Al}_{5-x} \mathrm{O}_{12}$ ceramics exhibited five times broader emission bandwidth than that of Nd : YAG with a composition parameter of $x=1$ [8]. The main aim of this study was the sol-gel preparation and detailed characterization of lanthanide-doped $\mathrm{Y}_{3} \mathrm{Sc}_{2} \mathrm{AlGa}_{2} \mathrm{O}_{12}$.

\section{Experimental}

The Nd: $\mathrm{Y}_{3} \mathrm{Sc}_{2} \mathrm{AlGa}_{2} \mathrm{O}_{12}$, Ho : $\mathrm{Y}_{3} \mathrm{Sc}_{2} \mathrm{AlGa}_{2} \mathrm{O}_{12}$, Er : $\mathrm{Y}_{3} \mathrm{Sc}_{2} \mathrm{AlGa}_{2} \mathrm{O}_{12}, \mathrm{~Tb}: \mathrm{Y}_{3} \mathrm{Sc}_{2} \mathrm{AlGa}_{2} \mathrm{O}_{12}$, Dy : $\mathrm{Y}_{3} \mathrm{Sc}_{2} \mathrm{AlGa}_{2} \mathrm{O}_{12}$, and $\mathrm{Yb}: \mathrm{Y}_{3} \mathrm{Sc}_{2} \mathrm{AlGa}_{2} \mathrm{O}_{12}$ garnets were prepared by the sol-gel method. The Y(RE)Sc-Al-Ga-O precursor gels were prepared using stoichiometric amounts of the following analytical grade 


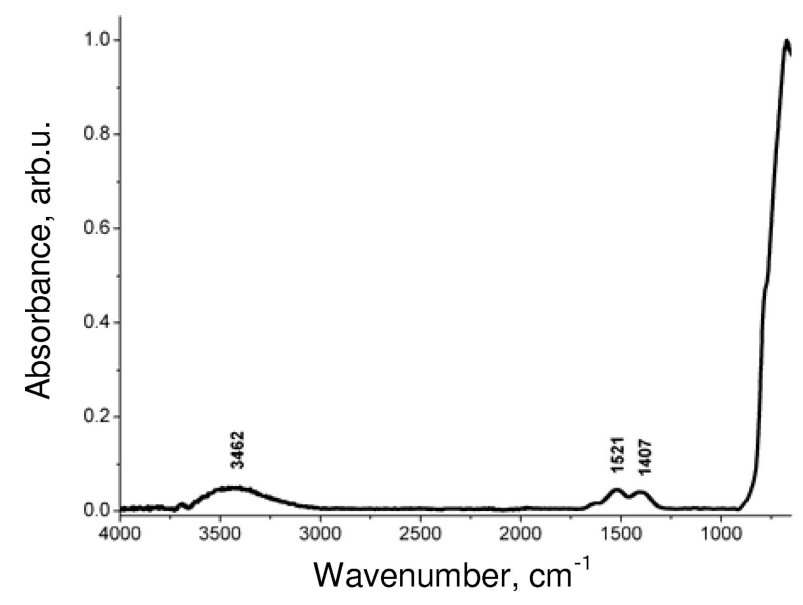

Fig. 1. FTIR spectrum of YSAGG sample calcined at $800^{\circ} \mathrm{C}$.

reagents: yttrium oxide $\mathrm{Y}_{2} \mathrm{O}_{3}$; scandium oxide $\mathrm{Sc}_{2} \mathrm{O}_{3}$; aluminium nitrate hydrate $\mathrm{Al}\left(\mathrm{NO}_{3}\right)_{3} \cdot 9 \mathrm{H}_{2} \mathrm{O}$; gallium nitrate $\mathrm{Ga}\left(\mathrm{NO}_{3}\right)_{3}$; neodymium oxide $\mathrm{Nd}_{2} \mathrm{O}_{3}$; holmium oxide $\mathrm{Ho}_{2} \mathrm{O}_{3}$; erbium oxide $\mathrm{Er}_{2} \mathrm{O}_{3}$; terbium oxide $\mathrm{Tb}_{4} \mathrm{O}_{7}$; dysprosium oxide $\mathrm{Dy}_{2} \mathrm{O}_{3}$; ytterbium oxide $\mathrm{Yb}_{2} \mathrm{O}_{3}$; acetic acid $\mathrm{CH}_{3} \mathrm{COOH}$; nitric acid $\mathrm{HNO}_{3}$; ammonia $\mathrm{NH}_{3} \cdot 4 \mathrm{H}_{2} \mathrm{O}$; 1,2-ethanediol $\mathrm{C}_{2} \mathrm{H}_{6} \mathrm{O}_{2}$.

In the sol-gel process, yttrium oxide was first dissolved in $0.2 \mathrm{M} \mathrm{CH}_{3} \mathrm{COOH}$. Since $\mathrm{Sc}_{2} \mathrm{O}_{3}$ and $\mathrm{Ga}_{2} \mathrm{O}_{3}$ are insoluble in acetic acid, they were initially dissolved in hot nitric acid and evaporated to dryness. A clear solution of yttrium acetate was obtained after stirring for $10 \mathrm{~h}$ at $65^{\circ} \mathrm{C}$ in a beaker covered with a watch glass. Aluminum nitrate dissolved in distilled water, scandium oxide, and gallium oxide dissolved in diluted nitric acid were added to this solution. The resulting mixture was stirred for $3 \mathrm{~h}$ at the same temperature. Next, an appropriate amount of dopant (oxide of rare-earth element) dissolved in nitric acid was added to the above solution. In a following step, $2 \mathrm{ml}$ of 1,2-ethanediol as a complexing agent was added to the above solutions with continuous stirring. After concentrating the solutions by slow evaporation $(\sim 8 \mathrm{~h})$ at $65^{\circ} \mathrm{C}$ in an open beaker under stirring the $\mathrm{Y}(\mathrm{RE})-$ $\mathrm{Sc}-\mathrm{Al}-\mathrm{Ga}-\mathrm{O}$ acetate-nitrate-glycolate sols turned into transparent gels. The oven dried $\left(110^{\circ} \mathrm{C}\right)$ gels became light brown due to the initial decomposition of nitrates. The gel powders were ground in an agate mortar, placed in alumina crucibles, and burned for $2 \mathrm{~h}$ at $800^{\circ} \mathrm{C}$ in air (heating rate $1^{\circ} \mathrm{C} \mathrm{min}-1$ ). After intermediate grinding in an agate mortar, the powders were additionally sintered for $10 \mathrm{~h}$ at $1000^{\circ} \mathrm{C}$ (heating rate $4{ }^{\circ} \mathrm{C} \min ^{-1}$ ) in air at ambient pressure.

The Fourier transform infrared (FTIR) spectra were measured with a Perkin Elmer 2000 FT-IR spectrometer. X-ray diffraction (XRD) studies were carried out

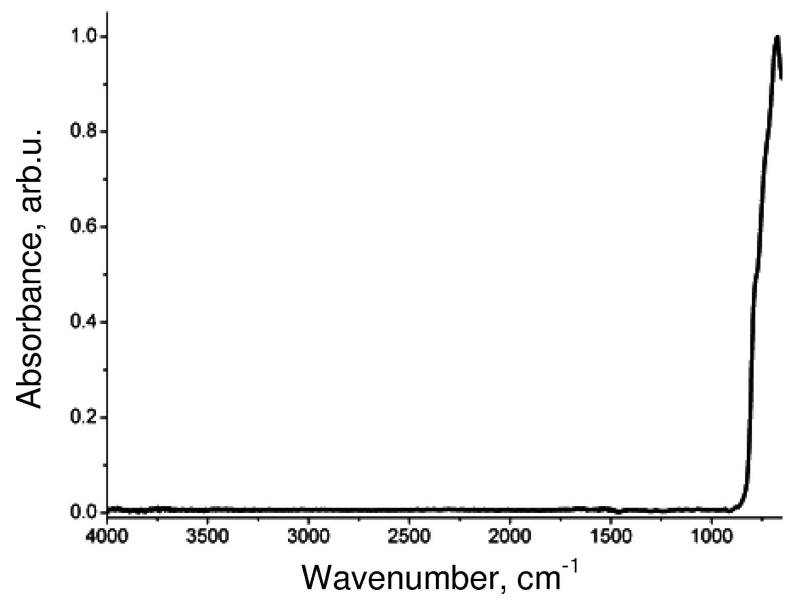

Fig. 2. FTIR spectrum of YSAGG sample sintered at $1000^{\circ} \mathrm{C}$.

Table 1. ICP analysis of the final RE: YSAGG samples (standard deviations within parentheses; $n=3$ ).

\begin{tabular}{cccccc}
\hline & \multicolumn{5}{c}{ Molar percentage of metals (\%) } \\
\cline { 2 - 6 } Compound & $\mathrm{Y}$ & $\mathrm{Sc}$ & $\mathrm{Al}$ & $\mathrm{Ga}$ & $\mathrm{RE}$ \\
\hline YSAGG & $37.5(7)$ & $24.7(5)$ & $14.0(7)$ & $23.8(4)$ & - \\
Dy:YSAGG & $37.8(8)$ & $23.9(5)$ & $13.7(5)$ & $24.2(5)$ & $0.4(2)$ \\
Er:YSAGG & $37.5(6)$ & $24.5(7)$ & $13.8(6)$ & $23.8(5)$ & $0.4(3)$ \\
Ho: YSAGG & $37.8(5)$ & $24.3(8)$ & $13.6(7)$ & $24.1(5)$ & $0.2(2)$ \\
Yb:YSAGG & $37.0(4)$ & $25.3(5)$ & $13.2(9)$ & $23.6(5)$ & $0.9(5)$ \\
Nd:YSAGG & $37.6(4)$ & $25.7(6)$ & $13.6(4)$ & $22.8(5)$ & $0.3(1)$ \\
Tb: YSAGG & $34.2(9)$ & $25.5(8)$ & $14.1(4)$ & $25.8(5)$ & $0.4(4)$ \\
\hline
\end{tabular}

on a Rigaku D/max-2000 X-ray powder diffractometer using $\mathrm{Cu} \mathrm{K} \mathrm{K}_{\alpha}(\lambda=1.5408 \AA)$ radiation. The inductively coupled plasma atomic emission spectroscopy (ICP-AES, Plasma-Spec, Leeman Labs, Inc.) was used to analyse the chemical composition of final products. The size and morphology of the products were characterized by scanning electron microscopy (SEM, AMARY 1910FE, USA) at $15 \mathrm{kV}$. TEM images were taken with a JEOL 200CX transmission electron microscope under working voltage of $160 \mathrm{kV}$.

\section{Results and discussion}

To obtain YSAGG or RE : YSAGG phases the $\mathrm{Y}(\mathrm{RE})-\mathrm{Sc}-\mathrm{Al}-\mathrm{Ga}-\mathrm{O}$ acetate-nitrate-glycolate precursor gels were calcined and sintered at $800-1000{ }^{\circ} \mathrm{C}$. All ceramic samples obtained were characterized by FTIR spectroscopy. FTIR spectra of all samples were qualitatively the same regardless of the nature of substitution. The representative FTIR spectrum of YSAGG ceramics calcined at $800^{\circ} \mathrm{C}$ is shown in Fig. 1. The FTIR spectra of the YSAGG samples calcined at $800{ }^{\circ} \mathrm{C}$ contain broad bands at $3450-3470 \mathrm{~cm}^{-1}$ which are assigned to the adsorbed water. Besides, the FTIR spec- 


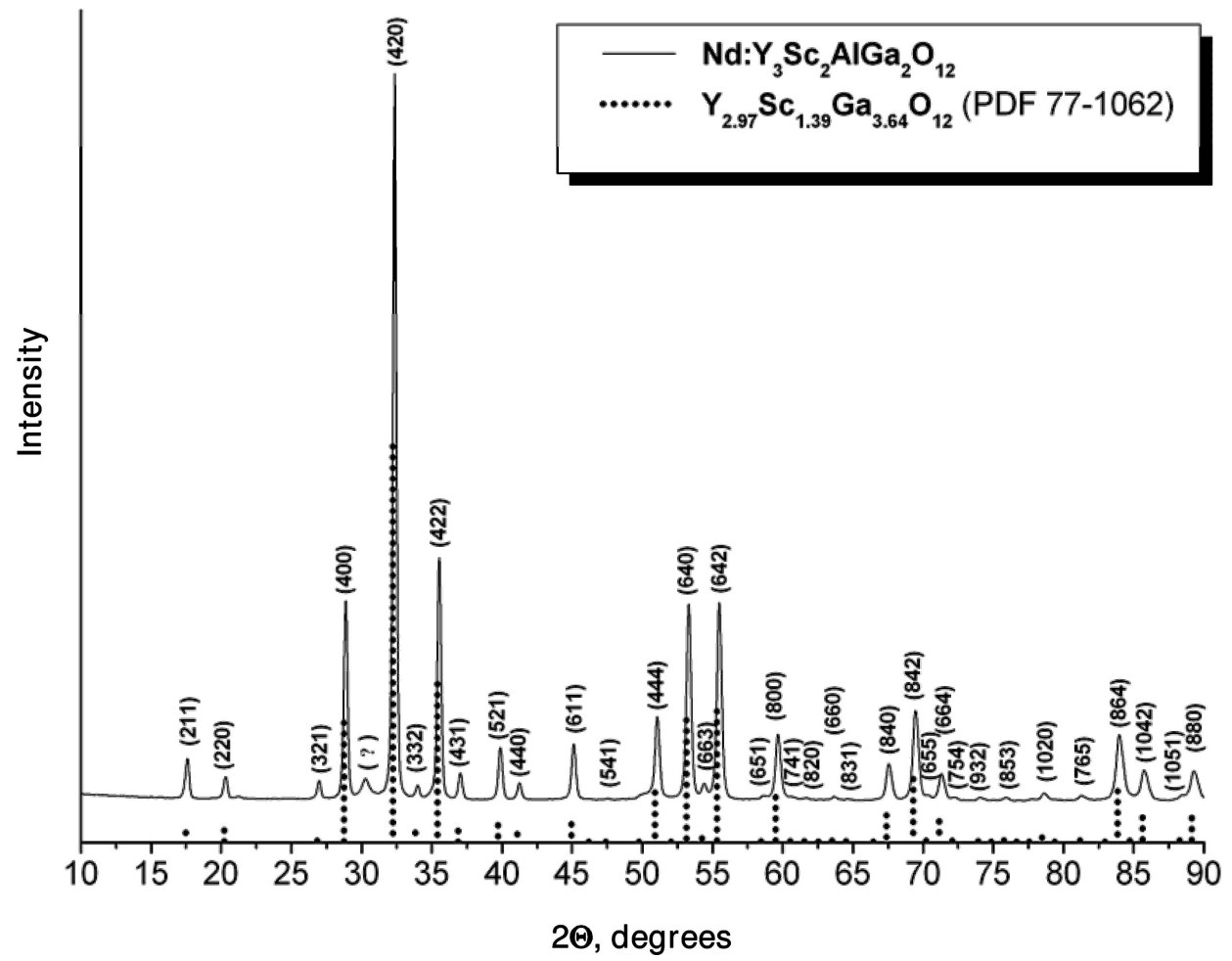

Fig. 3. XRD pattern of Nd: YSAGG sample.

tra of intermediate synthesis products obtained exhibit the bands at $\sim 1520$ and $\sim 1405 \mathrm{~cm}^{-1}$, assignable to carbonates. In addition, there is a broad and intensive band (900-650 $\left.\mathrm{cm}^{-1}\right)$ assigned to characteristic metal-oxygen $(\mathrm{M}-\mathrm{O})$ vibrations. The FTIR spectra of samples calcined at $1000{ }^{\circ} \mathrm{C}$, however, do not show any band attributable to carbonates or which can be assigned to the adsorbed water, and only $\mathrm{M}-\mathrm{O}$ stretching frequencies are observed. The FTIR spectrum of the representative YSAGG sample calcined at $1000^{\circ} \mathrm{C}$ is shown in Fig. 2. Therefore, from the FTIR spectroscopy results we can conclude that the formation of the YSAGG garnet phase starts at $1000^{\circ} \mathrm{C}$.

FTIR results are also consistent with the crystallization process observed by XRD measurements. The XRD patterns of different synthesis products obtained at $1000^{\circ} \mathrm{C}$ were identical. As seen in Fig. 3, the calcination of RE: Y-Sc-Al-Ga-O acetatenitrate-glycolate precursor gel at $1000{ }^{\circ} \mathrm{C}$ produces the fully crystalline $\mathrm{Nd}: \mathrm{Y}_{3} \mathrm{Sc}_{2} \mathrm{AlGa}_{2} \mathrm{O}_{12}$ garnet phase. For comparison, the XRD pattern of known $\mathrm{Y}_{2.97} \mathrm{Sc}_{1.39} \mathrm{Ga}_{3.64} \mathrm{O}_{12}$ (PDF 77-1062) is also included in Fig. 3. Thus, the XRD data confirm $\mathrm{Y}_{3} \mathrm{Sc}_{2} \mathrm{AlGa}_{2} \mathrm{O}_{12}$ to be the main crystalline component. All single lines are indexed, and only one unindexed line at around $2 \Theta \approx 30.5^{\circ}$ could be observed.

The elemental analysis of YSAGG and RE : YSAGG ceramic samples was performed using ICP spectro-

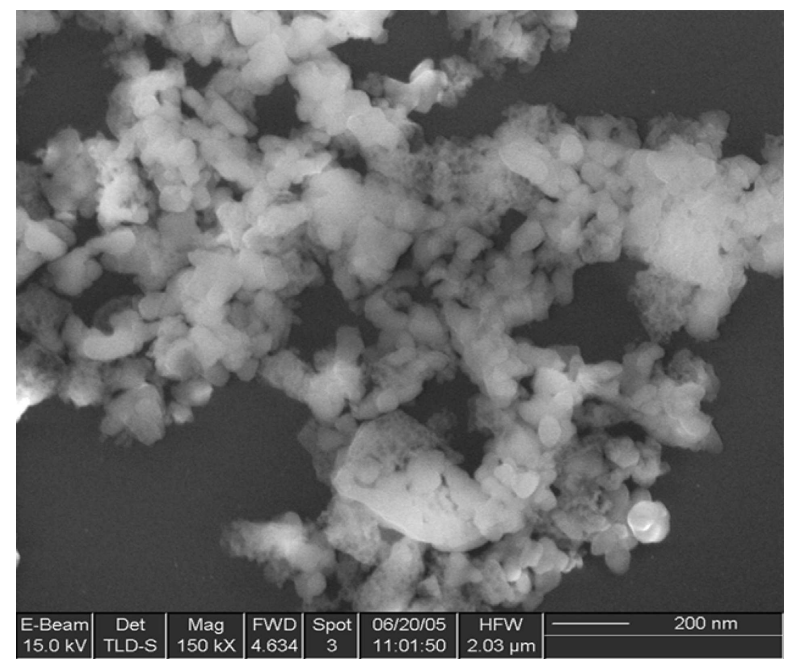

Fig. 4. SEM micrograph of YSAGG sample sintered at $800^{\circ} \mathrm{C}$. Magnification $150 \mathrm{k} \times$.

scopy. The amount of specimens taken for the analysis varied in the range of $0.00218-0.0306 \mathrm{~g}$. The results of ICP analysis are presented in Table 1. As seen, the metal content in the specimens practically does not depend on the lanthanide metal used in the synthesis process, indicating high reproducibility of the used sol-gel preparation technique. Only in the case of $\mathrm{Tb}$ : YSAGG, the amount of yttrium is a bit lower, while the content of gallium is higher. However, an important conclusion is that the compositions of all syn- 


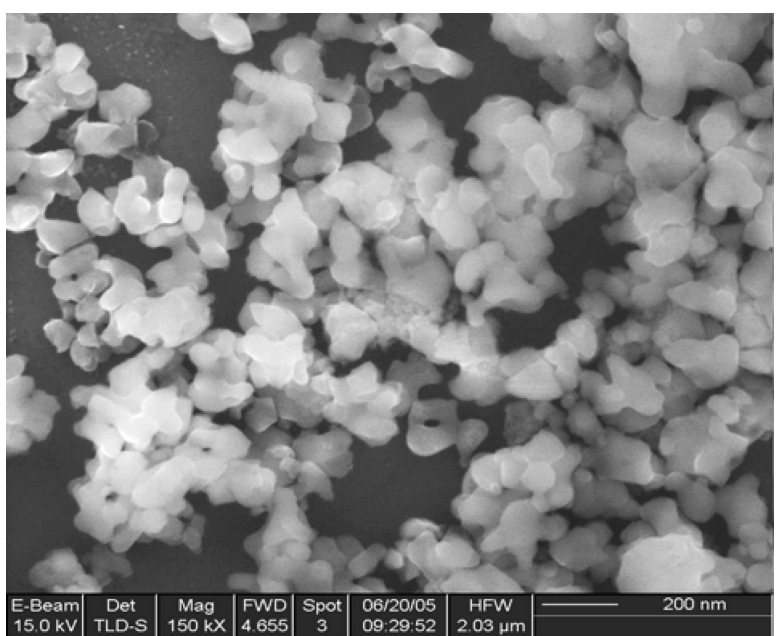

Fig. 5. SEM micrograph of $\mathrm{Tb}$ : YSAGG sample sintered at $1000^{\circ} \mathrm{C}$. Magnification $150 \mathrm{k} \times$.

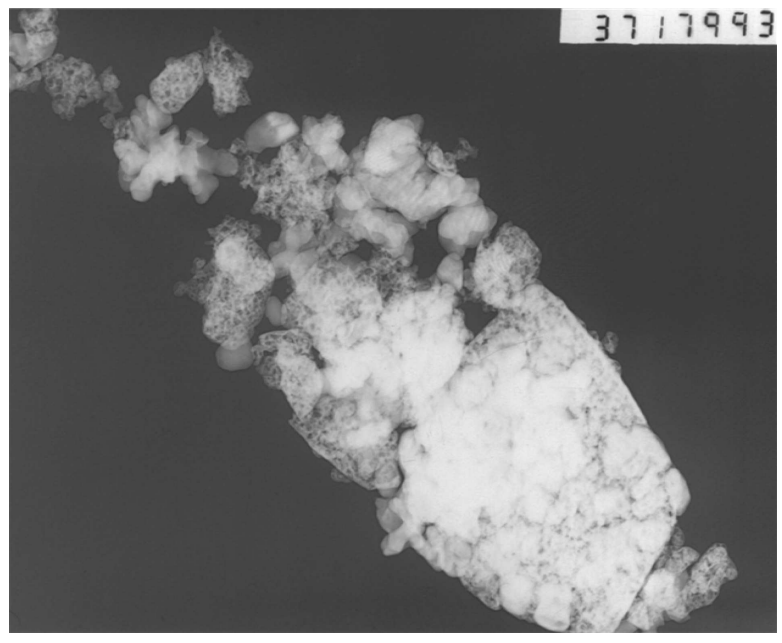

Fig. 6. TEM micrograph of YSAGG sample calcined at $800^{\circ} \mathrm{C}$. Magnification $75 \mathrm{k} \times$.

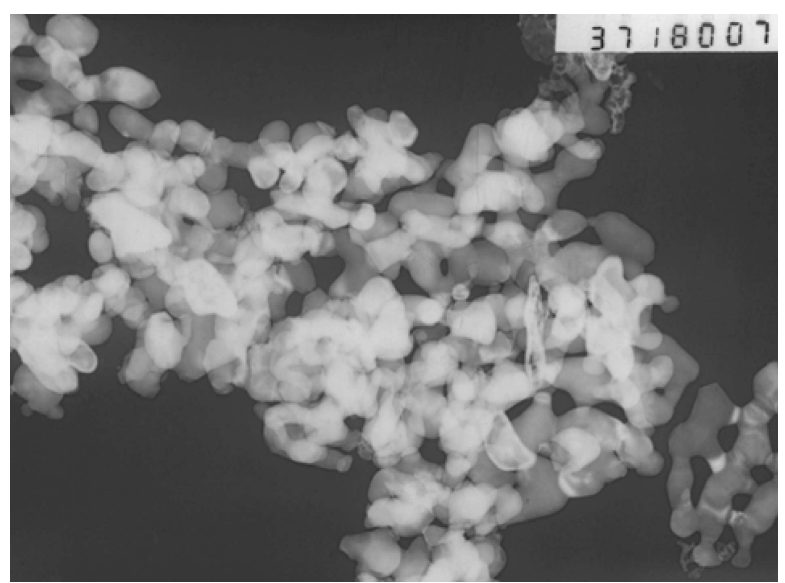

Fig. 7. TEM micrograph of $\mathrm{Yb}$ : YSAGG sample sintered at $1000^{\circ} \mathrm{C}$. Magnification $75 \mathrm{k} \times$. thesis products are rather homogeneous, as seen from the standard deviations. Using the data summarized in Table 1, the approximate chemical formula of synthesized garnets could be suggested:

$$
\begin{aligned}
& \mathrm{Y}_{3.0(4)} \mathrm{Sc}_{1.9(3)} \mathrm{Al}_{1.1(2)} \mathrm{Ga}_{1.9(3)} \mathrm{O}_{12} ; \\
& \mathrm{Dy}_{0.03(1)} \mathrm{Y}_{3.0(3)} \mathrm{Sc}_{1.9(2)} \mathrm{Al}_{1.1(2)} \mathrm{Ga}_{1.9(4)} \mathrm{O}_{12} ; \\
& \mathrm{Er}_{0.03(1)} \mathrm{Y}_{3.0(1)} \mathrm{Sc}_{1.9(3)} \mathrm{Al}_{1.1(1)} \mathrm{Ga}_{1.9(1)} \mathrm{O}_{12} ; \\
& \mathrm{Ho}_{0.02(1)} \mathrm{Y}_{3.0(3)} \mathrm{Sc}_{1.9(5)} \mathrm{Al}_{1.0(1)} \mathrm{Ga}_{1.9(3)} \mathrm{O}_{12} ; \\
& \mathrm{Yb}_{0.08(3)} \mathrm{Y}_{2.9(2)} \mathrm{Sc}_{2.0(4)} \mathrm{Al}_{1.0(2)} \mathrm{Ga}_{1.9(1)} \mathrm{O}_{12} ; \\
& \mathrm{Nd}_{0.03(1)} \mathrm{Y}_{3.0(2)} \mathrm{Sc}_{2.0(4)} \mathrm{Al}_{1.0(1)} \mathrm{Ga}_{1.8(3)} \mathrm{O}_{12} ; \\
& \mathrm{Tb}_{0.04(2)} \mathrm{Y}_{2.7(5)} \mathrm{Sc}_{2.0(5)} \mathrm{Al}_{1.1(3)} \mathrm{Ga}_{2.0(3)} \mathrm{O}_{12} .
\end{aligned}
$$

The morphological properties of ceramics synthesized at different temperatures were characterized by SEM and TEM measurements. Figure 4 shows surface features of the YSAGG sample synthesized at $800^{\circ} \mathrm{C}$. As seen in Fig. 4 the structure of intermediate synthesis products consists of agglomerates with highly porous and faceted grains. The SEM image of the $\mathrm{Tb}$ : YSAGG sample calcined at $1000^{\circ} \mathrm{C}$ is shown in Fig. 5. This SEM image exhibits clustered nanograins made up of several tiny crystallites with a defined structure. It can be seen in Fig. 5 that the Tb:YSAGG solids are composed of spherical grains. Individual particles seem to be nearly nano-sized crystals with an average particle size less than $50 \mathrm{~nm}$. Moreover, the SEM images also show a sinter-neck of a few nanoYSAGG particles which have different mutual orientation. It is interesting to note that almost identical surface microstructure and particle size were observed for all lanthanide-doped YSAGG garnet samples. Moreover, in all cases the nanoparticles are formed with very well pronounced agglomeration, indicating good connectivity between the grains. Evidently, the SEM results show that the morphological features of mixedmetal YSAGG garnets are independent of the nature of the dopant.

The TEM investigations once again confirmed high quality of synthesis products and reproducibility of the proposed sol-gel synthesis method. The analogous conclusions from TEM measurements could be drawn, as was indicated by SEM investigations. The TEM image of the YSAGG samples calcined at $800^{\circ} \mathrm{C}$ is shown in Fig. 6. The intermediate synthesis products consist of agglomerated crystallites having a different shape and size. The TEM image of the Yb : YSAGG sample, calcined at $1000^{\circ} \mathrm{C}$ (Fig. 7), also revealed agglomerated grains. Besides, the TEM image of $\mathrm{Yb}$ : YSAGG ceramics sintered at $1000{ }^{\circ} \mathrm{C}$ shows dispersed crystallites of nearly uniform size $(30-40 \mathrm{~nm})$. The TEM images of RE: YSAGG powders sintered at $1000^{\circ} \mathrm{C}$ also showed aggregation of crystallites as in the undoped 


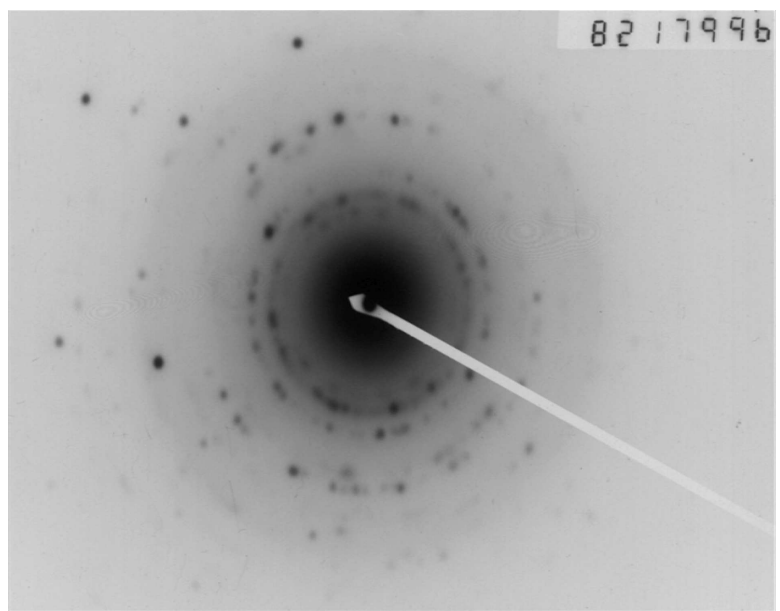

Fig. 8. Selected-area ED photograph of YSAGG sample sintered at $800{ }^{\circ} \mathrm{C}$.

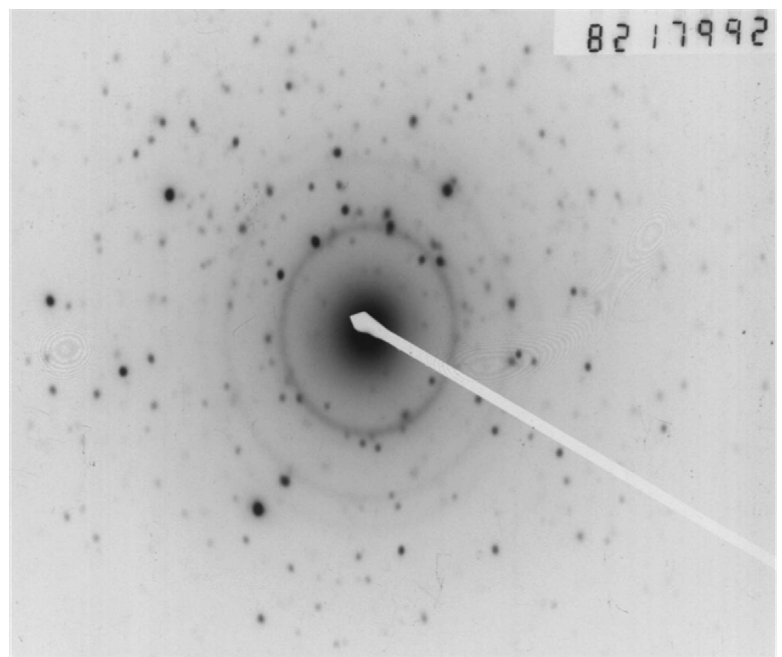

Fig. 9. Selected-area ED photograph of YSAGG sample sintered at $1000^{\circ} \mathrm{C}$.

YSAGG sample. The particle agglomeration caused by high sintering temperatures or the used synthesis method is evidently seen. Moreover, Fig. 7 shows the fusion of small YSAGG crystallites to form strangely shaped particles which grow further to form clusters of grains. The clustering tendency of the particles in the sol-gel synthesis may be due to the decomposition $\left(>900^{\circ} \mathrm{C}\right)$ of yttrium oxycarbonate or the traces of the "unburned" complexing agents (which may function as binder). Therefore, we can conclude that the grain structure and texture of the RE:YSAGG samples observed in transmission electron micrographs were similar to the pure YSAGG ceramics which supports the FTIR, XRD, and SEM observations where no other phase (e.g., perovskite or monoclinic) was detected.

Selected-area electron diffraction (ED) photographs were also obtained. The effused rings visible in Fig. 8 confirm that the YSAGG sample annealed at $800^{\circ} \mathrm{C}$ is partially amorphous and multiphase. The crystalline character could be easily determined from the ED image for the YSAGG sample sintered at $1000{ }^{\circ} \mathrm{C}$ which is presented in Fig. 9. However, it should be noted that in most cases the ED patterns were streaked along $a^{*}$. These streakings indicate that stacking faults, such as different point or planar defects, occur in the structure of synthesized garnets.

\section{Conclusions}

Using the aqueous sol-gel method, lanthanide-doped yttrium - scandium - aluminium - gallium mixed-metal garnets $\mathrm{Nd}: \mathrm{Y}_{3} \mathrm{Sc}_{2} \mathrm{AlGa}_{2} \mathrm{O}_{12}$, $\mathrm{Ho}: \mathrm{Y}_{3} \mathrm{Sc}_{2} \mathrm{AlGa}_{2} \mathrm{O}_{12}$, Er : $\mathrm{Y}_{3} \mathrm{Sc}_{2} \mathrm{AlGa}_{2} \mathrm{O}_{12}, \mathrm{~Tb}: \mathrm{Y}_{3} \mathrm{Sc}_{2} \mathrm{AlGa}_{2} \mathrm{O}_{12}$, Dy : $\mathrm{Y}_{3} \mathrm{Sc}_{2} \mathrm{AlGa}_{2} \mathrm{O}_{12}$, and $\mathrm{Yb}: \mathrm{Y}_{3} \mathrm{Sc}_{2} \mathrm{AlGa}_{2} \mathrm{O}_{12}$ (or $\mathrm{RE}$ : YSAGG) have been prepared. This study clearly revealed the formation of monophasic garnet materials. Besides, the homogeneous distribution of rare-earth dopants in the YSAGG lattice was achieved in all of the cases. The morphological characterization using SEM and TEM showed the formation of highly agglomerated nanocrystalline samples of nearly uniform size $(30-40 \mathrm{~nm})$. Electron diffraction patterns show the streaking effect which indicates that different defects occur in the crystal structure of synthesized garnets.

\section{Acknowledgements}

S. Šakirzanovas would like to thank Prof. Chunchua Yan (Peking University, China) for invaluable help performing this research and the Ministry of Science and Education of Lithuania for financial support to carry out work in the State Key Laboratory of Rare-Earth Materials Chemistry and Applications of Peking University.

\section{References}

[1] Y. Pan, M. Wu, and Q. Su, Tailored photoluminescence of YAG : Ce phosphor through various methods, J. Phys. Chem. Solids 65(5), 845-850 (2004).

[2] E. Garskaite, K. Gibson, A. Leleckaite, J. Glaser, D. Niznansky, A. Kareiva, and H.J. Meyer, On the synthesis and characterization of iron-containing garnets $\left(\mathrm{Y}_{3} \mathrm{Fe}_{5} \mathrm{O}_{12}, \mathrm{YIG}\right.$ and $\left.\mathrm{Fe}_{3} \mathrm{Al}_{5} \mathrm{O}_{12}, \mathrm{IAG}\right)$, Chem. Phys. 323(2-3), 204-210 (2006).

[3] I. Muliuoliene, D. Jasaitis, A. Kareiva, B. Blaschkowski, J. Glaser, and H.J. Meyer, Sol-gel synthesis and characterization of mixed-metal garnet $\mathrm{Y}_{3} \mathrm{ScAl}_{3} \mathrm{GaO}_{12}$ (YSAGG), J. Mater. Sci. Lett. 22(5), 349-351 (2003). 
[4] O.Yu. Goncharov, Evaluation of the parameters of cation distribution in $\mathrm{Y}_{3} \mathrm{~A}_{5-z} \mathrm{~B}_{z} \mathrm{O}_{12}$ solid solutions, Crystallography Rep. 48(1), 1-7 (2003) [in Russian: Kristallografiya 48(1), 7-13 (2003)].

[5] F. Maglia, V. Buscaglia, S. Gennari, P. Ghigna, M. Dapiaggi, A. Speghini, and M. Bettinelli, Incorporation of trivalent cations in synthetic garnets $\mathrm{A}_{3} \mathrm{~B}_{5} \mathrm{O}_{12}(\mathrm{~A}=\mathrm{Y}$, $\mathrm{Lu}-\mathrm{La}, \mathrm{B}=\mathrm{Al}, \mathrm{Fe}, \mathrm{Ga})$, J. Phys. Chem. B 110(13), 6561-6568 (2006).

[6] J. Saikawa, Y. Sato, T. Taira, and A. Ikesue, Passive mode locking of a mixed garnet $\mathrm{Yb}: \mathrm{Y}_{3} \mathrm{ScAl}_{4} \mathrm{O}_{12}$ ceramic laser, Appl. Phys. Lett. 85(24), 5845-5847 (2004).

[7] T.H. Allik, C.A. Morrison, J.B. Gruber, and M.R. Kokta, Crystallography, spectroscopic analysis, and lasing properties of $\mathrm{Nd}^{3+}: \mathrm{Y}_{3} \mathrm{Sc}_{2} \mathrm{Al}_{3} \mathrm{O}_{12}$, Phys. Rev. B 41(1), 21-30 (1990).

[8] J. Saikawa, Y. Sato, T. Taira, and A. Ikesue, Absorption, emission spectrum properties, and efficient laser performances of $\mathrm{Yb}: \mathrm{Y}_{3} \mathrm{ScAl}_{4} \mathrm{O}_{12}$ ceramics, Appl. Phys. Lett. 85(11), 1898-1900 (2004).

\title{
MIŠRIU METALU GRANATU SU LANTANOIDŲ PRIEMAIŠOMIS NANODALELIŲ SINTEZĖ ZOLIU IR GELIU METODU
}

\author{
S. Šakirzanovas, A. Kareiva \\ Vilniaus universiteto Chemijos fakultetas, Vilnius, Lietuva
}

\section{Santrauka}

Vandeniniu zoliu ir geliu metodu buvo susintetinti įvairūs mišrūs metalų granatai $\left(\mathrm{RE}: \mathrm{Y}_{3} \mathrm{Sc}_{2} \mathrm{AlGa}_{2} \mathrm{O}_{12}, \mathrm{RE}=\mathrm{Nd}, \mathrm{Ho}, \mathrm{Er}\right.$, Tb, Dy, Yb). FTIR ir XRD tyrimais irodyta, kad $1000{ }^{\circ} \mathrm{C}$ temperatūroje susidaro vienfazis mišrus metalų granatas. Nuodugnesni tyrimai (SEM, TEM, ICP) parodè, kad priemaišinio elemento prigimtis neturi įtakos gautu granatu morfologijai ir faziniam grynumui, nors elektronų difrakcijos nuotraukos rodo įvairius kristalinès gardelès defektus. 